\title{
The Sustainability of External Imbalances in the European Periphery
}

\begin{abstract}
The issue of external imbalances has become a key concern in the global economy, gaining particular prominence also inside Europe, following the Eurozone crisis. Comparatively, however, evidence for the European periphery is much less developed. In this study we investigate the sustainability of external imbalances in 15 countries from the EU's so-called eastern and super-periphery across a range of sustainability tests. We find that external imbalances are on the whole large and, despite some significant adjustments in the post-crisis period, they continue to follow paths that are possibly unsustainable. Our results show a higher likelihood of confirming sustainability when looking separately at the current account and the net foreign asset position than when looking jointly at the current and capital accounts (and thus at the intertemporal budget constraint - Bohn, 2007). This suggests, albeit tentatively, problems and vulnerabilities that go beyond simple concerns about price competitiveness and the trade performance of the countries under study.
\end{abstract}

Key Words: External imbalances, current account sustainability, European periphery, error correction

\section{Introduction}

The Eurozone crisis has explicated how external imbalances may cause destructive effects on an economy, either via accumulated differences in productivity (Camarero et al., 2013; Sinn, 2015) or due to sudden changes in the international environment (Lane and Pels, 2012; Obstfeld, 2012; Atoyan et al., 2013). The crisis has naturally focused much of policy and academic attention on the 'Eurozone south' (see, interalia, Arghyrou et al., 2008; Zemanek et al., 2010; Belke and Drager, 2013; Semmler and Tahri, 2017). The issue, however, is arguably much more pertinent in the case of emerging and transition economies - such as those located in the 'European 
periphery' and 'super-periphery' (Bartlett and Prica, 2013). ${ }^{1}$ For these countries, economic liberalisation, openness (integration) and convergence can cause significant current account derailments, not only due to the associated - but relatively benevolent - increased capital inflows (Roubini and Wachtel, 1998; Blanchard and Giavazzi, 2002) but also due to the implementation of - otherwise well-intended stabilisation policies (currency pegs, high interest rates) which tend to lower exportcompetititveness and depress domestic investment.

Despite this, the empirical literature on the topic covering this geographical region is rather limited. A limited number of studies have examined current account deficits and external imbalances in the countries of Central and Eastern Europe, showing that for these countries imbalances have been accumulating already since the 1990 s (e.g., Harkmann and Staehr, 2012). But for the countries in the 'super-periphery' the literature is really scarce and underdeveloped (cf. Muharremi, 2016) with the bulk of the empirical evidence coming from policy studies published by the European Commission and the IMF.

In this paper we attempt to fill this gap by providing a comprehensive analysis of the sustainability of external imbalances in the countries of the European 'periphery' and 'super-periphery'. We go beyond traditional approaches to the issue, which typically utilise unit root and cointegration tests on relevant aggregates (current accout balance and net foreign assets position for unit root tests; exports and imports-

\footnotetext{
${ }^{1}$ The term is used to describe the New Member States of the 2004/13 enlargements ('periphery') and the EU candidate and associated countries (Western Balkans, Turkey and Eastern Partnership) ('superperiphery').
} 
augmented series ${ }^{2}$ for cointegration analysis), in two ways. First, by testing jointly the dynamics of a country's net exports (a proxy for the current account) and its net foreign assets position (a proxy for the capital account) following a relatively novel approach (Bohn, 2007), which relies on a non-linear estimation of an error-correction model incorporating these two aggregates. Second, by utilising an adjusted series on net foreign assets, which allows us to control for the so-called "valuation channel" (see Gourinchas and Rey, 2007 and Ghironi et al., 2015), i.e., for changes in the capital account that are due not to capital movements per se but to capital gains/losses on a country's external assets and liabilities, including via exchange rate changes. ${ }^{3}$ We implement our analysis for each country separately over two sub-periods, seeking to examine how and whether external sustainability was affected by the global financial crisis; but for robustness we also examine sustainability for the full period under analysis, allowing for structural breaks to come out endogenously from our estimations.

Our empirical results offer unique insights into the question of current account sustainability in the countries of the EU periphery and super-periphery and vindicate our choice to examine the issue under multiple methodologies. Results from the traditional unit root tests for the stationarity of the current account balance and net foreign assets position confirm sustainability in a majority of countries (both prior to and during the crisis). However, the cointegration analysis confirms sustainability in a much smaller group of countries and mainly in the second period; while the error

\footnotetext{
2 Imports-augmented is the imports of goods and services series that is adjusted for interest and transfer payments thus incorporating changes in the financial account.

${ }^{3}$ The valuation channel is juxtaposed to the so-called 'trade channel', which concerns changes in the current account due to shifts in the exports and imports series (Gourinchas and Rey, 2007).
} 
correction approach, which incorporates the net foreign assets position, finds sustainability for only two cases (Macedonia and Turkey) and only during the crisis period. As the less restrictive, but also less narrow, test produces the weakest evidence for sustainability, we are forced to conclude that (a) external positions in the EU periphery are largely unsustainable, even after the corrections that have occurred during the crisis; and that (b) unsustainability derives mainly from developments and fluctuations in financial aggregates (net foreign assets positions and the valuation channel) than in real aggregates (exports-imports and the trade channel). This finding suggests a particular vulnerability for the countries of the EU periphery, which links not so much to their export capacity and trade competitiveness but to the robustness of their currencies and the sustainability of (and their dependence on) foreign capital inflows.

The remainder of the paper proceeds as follows. In the next section we provide a brief review of the relevant literature, explaining also how methods and approaches developed over time. Section 3 presents our econometric approach and our data set. Section 4 presents the results from our analysis, including a discussion of descriptive patterns and the econometric examination of sustainability under the three methodologies (unit root, cointegration and error-correction tests). The last section concludes with a discussion of the policy relevance and implications of our analysis. 


\section{Literature Review}

Existing studies in the literature of external sustainability can be split into three main groups: studies examining the stationarity of the current account (CA) balance or net foreign assets (NFA) position applying unit root techniques; studies focusing on the existence of a long-run relationship between exports and imports-augmented through cointegration analyses; and, more recently, studies that incorporate in their analysis jointly the dynamics of net foreign assets and the current account, following a methodological approach relying on the non-linear estimation of an error correction model.

Studies in the first group have tended to reach divergent conclusions, depending on the type of series examined (e.g., net investment position versus current account) and the type of test performed (e.g., allowing for structural breaks or non-linearities). For example, Trehan and Walsh (1991) found evidence of sustainability when examining the US net investment position in simple unit root tests; but under similar tests Wickens and Uctum (1993) found evidence against sustainability when looking at the country's current account balance. Looking at sub-samples of OECD countries, Liu and Tanner (1996) found sustainability to be accepted only under the assumption of country-specific structural breaks, while Wu (2000) found evidence in favour of sustainability only under a panel unit root test but not for individual countries. In more recent studies, researchers draw on newly developed techniques in order to take into account possible structural breaks in the series. For example, Kuo (2016) found evidence of sustainability for six Asian countries (Taiwan, Korea, the Philippines, Thailand, Singapore and Japan) in a quantile autoregression (QAR) 
framework which considers the influence of shocks with different signs and magnitudes on current accounts. In another study, Andre et al. (2018) came to the conclusion that current accounts were sustainable in G7 and BRICS countries by applying long memory models and by allowing for structural breaks in these models. Similarly, other studies have shown sustainability to hold only under the assumption of non-linearity in the current account series (e.g., Christopoulos and Leon-Ledesma, 2010, for the US; Lau et al., 2006, for a sample of South East Asian countries; Chen and Xie, 2015, for a sample of OECD countries; Hasdemir et al., 2019, for BRICS countries).

Studies in the second group (examining the long-run relationship between exports and imports) have also produced varied results, depending on the data and method used. Typically, sustainability tends to be rejected under simpler tests (e.g., Husted, 1992, using Engle-Granger (1987) cointegration test; Wu et al., 1996, using the Johansen-Juselius (Johansen, 1988; Johansen and Juselius, 1990) and Gregory-Hansen (1996) cointegration tests; Afonso et al., 2018, for 22 EU countries using the Johansen-Juselius (Johansen, 1988; Johansen and Juselius, 1990) cointegration test), while evidence of sustainability is found more commonly when allowing for structural breaks (e.g., Apergis et al., 2000, for Greece) or country-specific heterogeneity in a panel-cointegration setting (e.g., Wu et al., 2001, for the G7 countries; Holmes, 2006, for 11 OECD countries using Pedroni (1999, 2004)'s panel cointegration test; Llorca, 2017, for 24 Asian countries using Pedroni (1999, 2004)'s and Westerlund (2007)'s panel cointegration tests; Oyon-Amba et al., 2017, for eight Economic Community of Central African States (ECCAS) using panel and intra-panel cointegration analysis; 
Shastri et al., 2018, for five South Asian countries using Westerlund (2007)'s panel cointegration test). In a recent study, Saho et al. (2016) apply Bayer-Hanck (2013) combined cointegration test to assess the sustainability of current account balance in China and India. Bayer-Hanck (2013) cointegration test combines information from individual cointegration tests. By using this new methodology Saho et al. (2016) found evidence of sustainability only for China in the long-run.

As we discuss in more detail in the next section, approaches using unit root or cointegration techniques have recently been criticised for suffering from two main shortcomings. First, that they impose too strict a condition for CA sustainability, thus overlooking the fact that first-order difference-stationarity is not a necessary condition for the intertemporal budget constraint (and thus current account sustainability) to hold (Bohn, 2007). Second, that they focus solely on the "trade channel", which links current foreign liabilities to future trade surpluses, thus failing to factor-in the effects of capital gains and losses arising from increasing capital flows on international investment positions - what Gourinchas and Rey (2007) describe as the "valuation channel" for the adjustment of external imbalances. In both cases, the implication is that inferences concerning current account sustainability based on traditional unit root and cointegration tests become questionable. Responding to this criticism, a small number of studies have emerged more recently that examine the issue of CA sustainability by including the changes in net foreign assets to the empirical analysis. Durdu et al. (2013) examined the external solvency of 50 industrialised and emerging economies (for 1970-2006), finding external imbalances to be more sustainable in countries with stronger fundamentals in terms of 
institutional quality, financial sector development, trade openness and flexibility of exchange rate regimes. Significant country heterogeneity, under the same methodology, has also been found by Bajo-Rubio et al. (2014) for the OECD as well as by Camarero et al. (2013), who further demonstrated how country-specific results change when not accounting for valuation effects, the intertemporal budget constraint and potential structural breaks. Schoder et al. (2013) used this methodology to examine the sustainability of external imbalances in the Euro area, focusing on the implemantation of the EMU convergence criteria in 1997 and finding that the introduction of the Euro aggravated problems of external imbalances.

Evidence concerning the sustainability of external (im)balances in the EU's 'eastern' and 'super-periphery', in the tradition of the literature reviewed above, is much more scant (Sadiku et al., 2015; Muharremi, 2016). Studies examining the issue are often more descriptive, focusing on specific policy questions (e.g., exchange rate pegs) for sub-sets of countries, and generally reporting large and persistent imbalances but without formal testing of their sustainability (see, inter alia, Aristovnik, 2008; Herrmann and Winkler, 2009; Ca'Zorzi et al., 2009; Purfield and Rosenberg, 2010; Kang and Shambaugh, 2013; Cuestas, 2013; Bollano and Ibrahimaj, 2015; and Muharremi, 2016). As noted already, our analysis in this paper seeks to fill this gap, by examining the issue of sustainability comparatively for the countries of the EU's 'eastern' and 'super-periphery' and utilising the range of methodologies coming from the three streams of literature reviewed above. We explain our methodological approach in the next section. 


\section{Econometric Approach and Data}

As noted previously, traditionally empirical analyses of external sustainability rely on tests for the order of integration (unit root tests) of the current account balance or the net foreign assets position of a country; and tests for the presence of a cointegration relationship between a country's exports and imports. ${ }^{4}$ More recently, a new approach to testing the sustainability of CA positions has emerged in the literature which provides a less restrictive and more comprehensive test. The approach, proposed by Bohn (2007), takes directly into account the relationship between the current and capital accounts, through estimation of an error correction model which tests for the presence of a long-run relationship between net foreign assets (i.e., the capital account position) and net exports (i.e., exports of goods and services minus imports of goods and services which represents a country's current account position without interest and transfer payments). This has two advantages. First, intuitively, it allows for sustainability in cases where an 'unsustainable' current account position is corrected by a mirror position in the capital account (and vice versa). Second, econometrically, it reduces the probability of 'type-2' errors (i.e., the erroneous rejection of stationarity) as it provides a less restrictive sufficient condition for sustainability (high-order difference-stationarity). ${ }^{5}$

\footnotetext{
${ }^{4}$ Strictly speaking, this tests sustainability in the trade balance. To look the current account balance typically the imports series is adjusted for interest and transfer payments thus incorporating changes in the financial account ("imports-augmented"). We follow this approach in our study.

${ }^{5}$ As demonstrated by Bohn (2007), high-order difference-stationarity is sufficient for sustainability (in the form of the intertemporal budget constraint) to hold and thus the condition used in the importsaugmented-exports cointegration analysis (first-order difference-stationarity) is unnecessarily restrictive. Note, however, that neither approach provides a necessary condition test for sustainability.
} 
In this study we use both sets of approaches (i.e., the methodology proposed by Bohn, 2007; and the traditional analyses of current account and net foreign assets stationarity and exports-imports-augmented cointegration) as we want to obtain the fullest amount of information possible from our data. To assess the stationarity of the CA and NFA series we use the generalised least squares (GLS) detrended version of the conventional Dickey-Fuller test (DFGLS or ERS test) proposed by Elliott et al. (1996) and a modified version of the Phillips-Perron tests proposed by Ng and Perron (2001). Both of these tests perform better than the traditional unit root tests especially when the length of the series is short, as is the case with our analysis. In order to investigate the cointegration relationship between exports and importsaugmented we draw on the traditional Johansen cointegration test (Johansen, 1988; Johansen and Juselius, 1990), which has been shown to combine both good power and good size properties in comparison to the other tests in the literature (Hubrich et al., 2001).

Following, we apply the methodology of Bohn (2007). We first investigate the order of integration of exports, imports and net foreign assets by using the DFGLS and NgPerron unit root tests. Then, we estimate the following error-correction specification, for every country in our sample, by means of non-linear least squares:

$$
\Delta n x_{t}=\alpha+\delta\left(n x_{t-1}-\beta n f a_{t-2}\right)+\theta(L) \Delta n x_{t-1}+\gamma(L) \Delta n f a_{t-1}+\varepsilon_{t}
$$

In this equation, $\boldsymbol{n} \boldsymbol{x}$ represents net exports (exports of goods and services minus imports of goods and services) and $\boldsymbol{n f a}$, which in this model enters with a two-period lag, represents net foreign assets (both as a ratio to GDP); while $\boldsymbol{\varepsilon}, \boldsymbol{\Delta}$ and $\boldsymbol{L}$ are the error term, difference operator and lag operator respectively. This specification 
allows us to test directly one of the main propositions deriving from Bohn's (2007) analysis, which asserts that a country's current account balance will be sustainable if there is an error-correction relationship between its net exports and the past net foreign asset position with a cointegration coefficient $\rho$ such that $\rho<0$ and $|\rho| \epsilon(0,1+r)$ (Durdu et al., 2013: 767).

In line with the previous analyses in the literature we use the current account balance and net foreign assets positions for the unit root analysis, exports and importsaugmented series for cointegration tests and net exports (for Bohn's methodology net exports represents a country's current account position without interest and transfer payments) and net foreign assets positions for Bohn's approach.

Our data cover 15 countries from the European periphery and super-periphery over the period $1999-2012 .{ }^{6}$ We are constrained historically by data availability as for most of these countries data prior to the late 1990s are either non-reliable or simply not available. To overcome the implication of this for our sample size, we use quarterly data for all of our main series (exports of goods and services, imports of goods and services, imports of goods and services augmented with interest and transfer payments, net exports and current account balance), as derived from the IMF International Financial Statistics (IFS) (IMF, 2014). The only exception to this is the NFA series, which we have taken from the External Wealth of Nations Mark II database (Lane and Milesi-Ferretti, 2007). The database offers annual data covering the period only up to 2012 , but its NFA series is superior to that of other sources as it

\footnotetext{
${ }^{6}$ Belarus, Bulgaria, Croatia, Cyprus, Czech Republic, Greece, Hungary, Macedonia, Moldova, Poland, Romania, Slovakia, Slovenia, Turkey, and Ukraine. Greece is included due to both its geographical location and its salience in relation to the Eurozone crisis. Due to first-differencing of the variables of interest, our effective dataset starts at 2000q1.
} 
is adjusted to take into account changes in net foreign asset values that are due to valuation effects. We consider this an important feature of our analysis, as it is widely acknowledged in the literature that neglecting the valuation effect can produce results that are potentially unreliable or misleading (see, inter alia, Lane and MilesiFerretti, 2007; Gourinchas and Rey, 2007; Ghironi et al., 2015). To convert this annual data into quarterly series we use the Proportional First Differences Benchmarking Method developed by Denton (1971). Finally, to examine the potential influence of the Global Financial Crisis on the sustainability of external imbalances in our sample, in our core analysis we have split our dataset in two sub-periods, covering the quarters 2000q1-2007q4 and 2005q1-2012q4.7 In what follows, the presentation of our results is organised along the lines of these two sub-periods.

\section{Empirical Results}

\subsection{Descriptive evidence}

We start with a descriptive exploration of the patterns characterising our key variables of interest, namely the current account balance and the net foreign assets position (both expressed as a share of GDP). Starting from the current account balance (Figure 1), we observe that all countries under study have had negative

\footnotetext{
${ }^{7}$ We allow for these sub-periods to overlap somewhat in order to have sub-periods of sufficient (and equal) length. For Cyprus, Macedonia, Slovakia and Ukraine data coverage starts only in the early 2000 s and thus these countries are not included in the first sub-period. We have additionally implemented the full set of tests included in our core analysis for the full period covered by our data, allowing for endogenously estimated structural breaks.
} 
balances almost uninterruptedly throughout the period under consideration (19992012). However, for most countries (Belarus, Croatia, the Czech Republic, Hungary, Macedonia, Poland, Slovakia, Slovenia, Turkey and Ukraine) CA deficits have not been particularly alarming over the period and especially prior to the crisis - with CA deficits remaining for the vast majority of years within 5 percentage points of GDP. It is only for a subset of countries (Bulgaria, Cyprus, Greece, Moldova and Romania) that CA deficits appear substantially large - and thus possibly unsustainable - with typical values in the area of between 10-20 percent of GDP and episodes of significant deterioration even beyond the 20 percent mark (e.g., reaching $-28 \%$ in Cyprus in 2009). Irrespective of these differences, however, for both groups we observe that CA imbalances worsened in the run-up to the crisis. Still, the effect of the crisis appears also not to have been unifrom across space - with some countries experiencing really dramatic changes and others remaining rather unaffected by the crisis and experiencing positive re-adjustments thereafter. For instance, Bulgaria's current account deficit rose from around 11.5 percent of GDP in 2005 to 27.2 percent in 2007 but recovered very significantly after 2009. For Greece, the current account deficit also increased prior to the crisis (from 7.6 percent of GDP in 2005 to 15 percent in 2008), but the adjustment there has been much slower. In contrast, in countries such as Hungary, the Czech Republic, Slovakia and Croatia the current account balance showed little deterioration in the run-up to the crisis and remained within 10 percent of GDP throughout. 
Figure 1. Current Account Balance/GDP

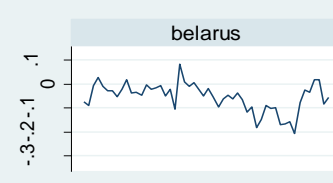

czech republic

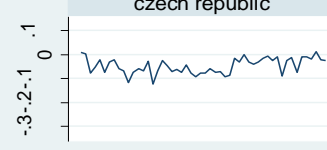

moldova
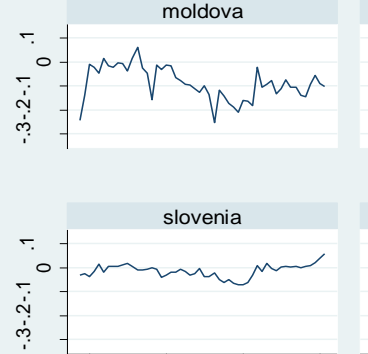

2000q3 2004q3 2008q3 2012q32000q3 2004q3 2008q3 2012q32000q3 2004q3 2008q3 2012q3

Graphs by countries

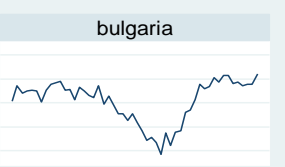

greece

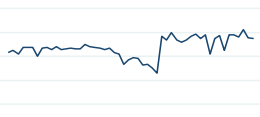

poland

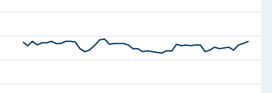

turkey

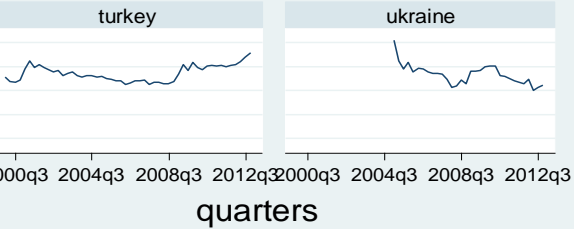

quarters croatia

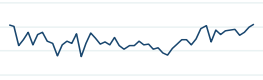

hungary

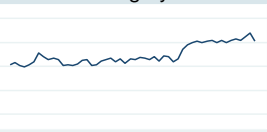

romania

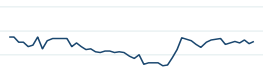

2000 3 2004q3 2008q3 2012q3

cyprus

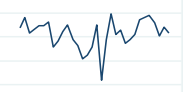

macedonia

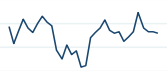

slovakia

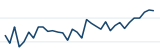

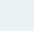

Source: IMF (International Monetary Fund) (2014). International Finanacial Statistics (IFS), https://data.imf.org/?sk=4C514D48-B6BA-49ED-8AB9-52B0C1A0179B, and authors' calculations.

The picture concerning net foreign assets positions is somewhat more uniform. As depicted in Figure 2, these have been negative in virtually all countriers (except Cyprus prior to 2007) and on a declining trend everywhere between 2000-2012. Still, there is a sometimes large variation in the extent of these imbalances. For just over half of the countries (Bulgaria, Belarus, Cyprus, the Czech Republic, Romania, Slovenia, Turkey and Ukraine) the average NFA position is high but below $45 \%$ of GDP. For the rest (Croatia, Greece, Hungary, Macedonia, Moldova, Poland and Slovakia), average NFA-to-GDP ratios are above or well-above $50 \%$. 
Figure 2. Net Foreign Assets/GDP

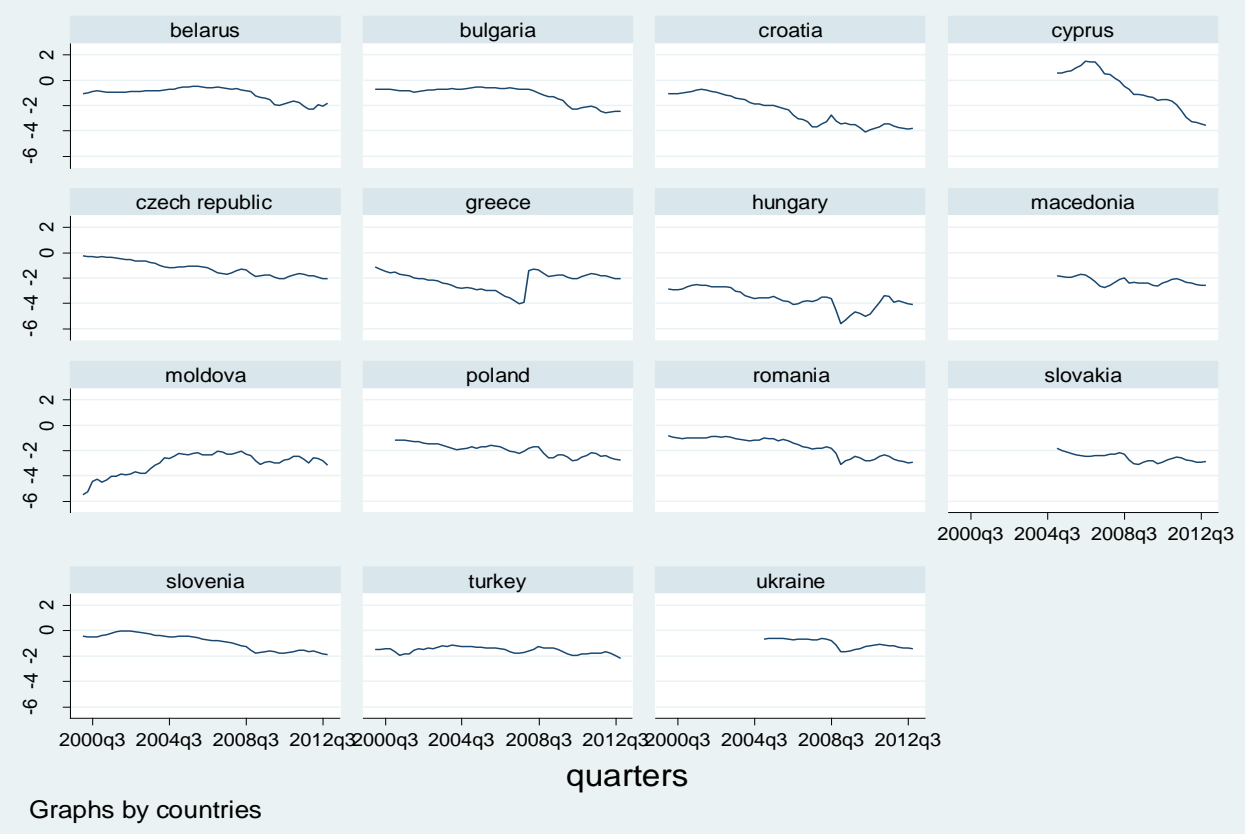

Source: Lane, P. R. and Milesi-Ferretti, G. M. (2007). "The External Wealth of Nations Mark II: Revised and Extended Estimates of Foreign Assets and Liabilities", 1970-2004", Journal of International Economics, 73(2), 223-250, and authors' calculations.

Note: The original data for NFA series is annual. Quarterly series are calculated by the authors using Denton (1971)'s methodology.

On the whole, the picture obtained from the descriptive analysis seems to suggest some problems of external imbalance, which are mostly related to the capital account (net foreign assets), as for most countries current account deficits have not been particularly high and have seen substantial corrections after the crisis. Interestingly, however, the majority of countries experiencing today the most significant problems with regard to their net foreign asset positions are also those countries which experienced huge current account deficits just before the 2008 Global Financial Crisis. This suggests possibly a cumulative relationship between the two aggregates, whereby NFA positions deteriorate under the influence of rising CA deficits. 


\subsection{Evidence from traditional tests}

Moving beyond the descriptive analysis, we proceed by examining the issue of sustainability econometrically, focusing in this sub-section on the traditional approaches to the issue. Starting from the unit root analysis, we note that our investigation includes a large number of tests (DFGLS and four variants of the $\mathrm{Ng}$ Perron statistic), over two periods (2000q1-2007q4 and 2005q1-2012q4), which cannot be presented in full here. For ease of presentation, we present in Table 1 the results from the unit-root tests in summary form and report the full set of results in Online -Resource 1 and Online Resource 2. In Table 1, while mentioning the name of the test means that the null hypothesis of unit root is rejected at either $1 \%$ or $5 \%$ significance levels, a hyphen shows that we cannot reject the null hypothesis and hence the series has unit root. As can be seen, the results from the unitroot tests provide rather widespread evidence in favour of sustainability for a large number of countries. For the pre-crisis period evidence of current account sustainability is consistently found, across tests, for the cases of Belarus, Croatia, the Czech Republic, Hungary,Moldova, Poland, Romania and Slovenia; while evidence of sustainability on the basis of the NFA positions is found for Belarus, Croatia, the Czech Republic, Greece, Hungary, Slovenia and Turkey. ${ }^{8}$ In this period, evidence of sustainability appears more robust for Belarus, Croatia, the Czech Republic, Hungary and Slovenia, in the sense that for these countries both their CA balance and their NFA position appear stationary.

\footnotetext{
${ }^{8}$ Recall that due to data limitations we do not examine in this first period the cases of Cyprus, Macedonia, Slovakia and Ukraine.
} 
Table 1. Unit-root tests for the Current Account and NFA series - summary results

\begin{tabular}{|c|c|c|c|c|}
\hline \multirow{2}{*}{ Country } & \multicolumn{2}{|c|}{ CA } & \multicolumn{2}{|c|}{ NFA } \\
\hline & $2000-2007$ & 2005-2012 & $2000-2007$ & 2005-2012 \\
\hline Belarus & $\begin{array}{c}\text { DFGLS; Ng-Perron } \\
\text { (MZa/MZt/MSB/MPT) }\end{array}$ & DFGLS & $\begin{array}{c}\text { Ng-Perron } \\
\text { (MZa/MZt/MSB/MPT) }\end{array}$ & - \\
\hline Bulgaria & 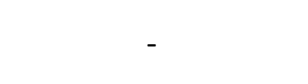 & $\begin{array}{c}\text { Ng-Perron } \\
\text { (MZa/MZt/MSB/MPT) }\end{array}$ & 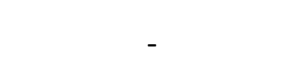 & - \\
\hline Croatia & $\begin{array}{c}\text { DFGLS; Ng-Perron } \\
\text { (MZa/MZt/MSB/MPT) }\end{array}$ & $\begin{array}{l}\text { Ng-Perron } \\
\text { (MZa / MSB) }\end{array}$ & $\begin{array}{c}\text { Ng-Perron } \\
\text { (MZa/MZt/MSB/MPT) }\end{array}$ & - \\
\hline Cyprus & $\mathrm{n} / \mathrm{a}$ & $\begin{array}{l}\text { DFGLS; Ng-Perron } \\
\text { (MZa/MZt/MSB/MPT) }\end{array}$ & $\mathrm{n} / \mathrm{a}$ & - \\
\hline Czech Rep. & $\begin{array}{c}\text { DFGLS; Ng-Perron } \\
\text { (MZa/MZt/MSB/MPT) }\end{array}$ & $\begin{array}{l}\text { DFGLS; Ng-Perron } \\
\text { (MZa/MZt/MSB/MPT) }\end{array}$ & $\begin{array}{c}\text { DFGLS; Ng-Perron } \\
\text { (MZa/MZt/MSB/MPT) }\end{array}$ & - \\
\hline Greece & - & - & $\begin{array}{l}\text { DFGLS; Ng-Perron } \\
\text { (MZa/MZt/MSB/MPT) }\end{array}$ & $\begin{array}{c}\text { Ng-Perron } \\
\text { (MZa/MZt/MSB/MPT) }\end{array}$ \\
\hline Hungary & $\begin{array}{c}\text { DFGLS; Ng-Perron } \\
\text { (MZa/MZt/MSB/MPT) }\end{array}$ & - & $\begin{array}{l}\text { DFGLS; Ng-Perron } \\
\text { (MZa/MZt/MSB/MPT) }\end{array}$ & $\begin{array}{l}\text { DFGLS; Ng-Perron } \\
\text { (MZa/MZt/MSB/MPT) }\end{array}$ \\
\hline Macedonia & $\mathrm{n} / \mathrm{a}$ & $\begin{array}{c}\text { DFGLS; Ng-Perron } \\
\text { (MZa/MZt/MSB/MPT) }\end{array}$ & $\mathrm{n} / \mathrm{a}$ & $\begin{array}{l}\text { DFGLS; Ng-Perron } \\
\text { (MZa/MZt/MSB/MPT) }\end{array}$ \\
\hline Moldova & DFGLS & $\begin{array}{c}\text { DFGLS; Ng-Perron } \\
\text { (MZa/MZt/MSB/MPT) }\end{array}$ & - & - \\
\hline Poland & $\begin{array}{l}\text { DFGLS; Ng-Perron } \\
\text { (MZa/MZt/MSB/MPT) }\end{array}$ & DFGLS & $\begin{array}{c}\text { Ng-Perron } \\
\text { (MZa/MZt/MSB/MPT) }\end{array}$ & - \\
\hline Romania & DFGLS & - & - & - \\
\hline Slovakia & $\mathrm{n} / \mathrm{a}$ & $\begin{array}{l}\text { DFGLS; Ng-Perron } \\
\text { (MZa/MZt/MSB/MPT) }\end{array}$ & $\mathrm{n} / \mathrm{a}$ & $\begin{array}{l}\text { Ng-Perron } \\
\text { (MZa / MSB) }\end{array}$ \\
\hline Slovenia & $\begin{array}{c}\text { DFGLS; Ng-Perron } \\
\text { (MZa/MZt/MSB/MPT) }\end{array}$ & 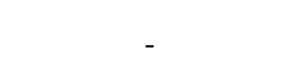 & $\begin{array}{l}\text { DFGLS; Ng-Perron } \\
\text { (MZa/MZt/MSB/MPT) }\end{array}$ & $\begin{array}{c}\text { Ng-Perron } \\
\text { (MZa/MZt/MSB/MPT) }\end{array}$ \\
\hline Turkey & - & DFGLS & $\begin{array}{c}\text { DFGLS; Ng-Perron } \\
\text { (MZa/MZt/MSB/MPT) }\end{array}$ & $\begin{array}{c}\text { Ng-Perron } \\
\text { (MZa/MZt/MSB/MPT) }\end{array}$ \\
\hline Ukraine & $\mathrm{n} / \mathrm{a}$ & - & $\mathrm{n} / \mathrm{a}$ & $\begin{array}{l}\text { DFGLS; Ng-Perron } \\
\text { (MZa/MZt/MSB/MPT) }\end{array}$ \\
\hline
\end{tabular}

Notes: DFGLS is the generalised least squares (GLS) detrended version of the conventional DickeyFuller test as proposed by Elliott et al. (1996). Ng-Perron includes four tests statistics, drawn from the previous literature and modified by $\mathrm{Ng}$ and Perron (2001). These are as follows: MZa and MZt correspond to the original unit-root tests proposed by Phillips and Perron (1988); MSB corresponds to the test proposed by Bhargava (1986); and MPT corresponds to the Point Optimal statistic proposed by Elliott et al. (1996). Full results from these tests are presented in the Online Resource 1 and Online Resource 2. $\mathrm{n} / \mathrm{a}$ indicates that the tests can not be estimated because of the data limitation.

In the second period the stationarity tests appear less strong and are statistically significant for fewer countries - suggesting that the sustainability of external imbalances declined in the crisis and post-crisis period. Sustainability in the current account is found only for the cases of Bulgaria, Cyprus, the Czech Republic, Macedonia, Moldova and Slovakia; while sustainability of NFA positions is found only 
for Greece, Hungary, Macedonia, Slovenia andTurkey. Thus, evidence of sustainability in this period is found consistently (across both measures) only for Macedonia; while, across periods, consistent evidence of sustainability is found in the case of the CA balance only forthe Czech Republic and Moldova and in the case of the NFA position for Greece, Hungary, Slovenia and Turkey.

Table 2. Johansen cointegration analysis between exports and imports

\begin{tabular}{|c|c|c|c|c|c|c|}
\hline Countries & Period & $\begin{array}{c}\text { Trace } \\
\text { Statistics }\end{array}$ & $\begin{array}{l}0.05 \mathrm{Cr} . \\
\text { Value }\end{array}$ & Probability & $\begin{array}{c}\text { Error- } \\
\text { Correction } \\
\text { Term } \\
\end{array}$ & $\begin{array}{l}\text { Long Run } \\
\text { Coefficient }\end{array}$ \\
\hline \multirow[t]{2}{*}{ Belarus } & $2000-2007$ & 22.3642 & 20.2618 & 0.0253 & 0.046418 & $-1.26209 * * *$ \\
\hline & $2005-2012$ & - & - & - & - & - \\
\hline \multirow[t]{2}{*}{ Bulgaria } & $2000-2007$ & 9.92939 & 15.4947 & 0.2862 & - & - \\
\hline & $2005-2012$ & 18.8638 & 15.4947 & 0.0149 & $-0.35598 * * *$ & $0.47885^{* *}$ \\
\hline \multirow[t]{2}{*}{ Croatia } & $2000-2007$ & & - & - & - & - \\
\hline & $2005-2012$ & 17.8403 & 15.4947 & 0.0218 & $-0.30044 * * *$ & $0.89488^{* *}$ \\
\hline \multirow[t]{2}{*}{ Cyprus } & $2000-2007$ & $\mathrm{n} / \mathrm{a}$ & $\mathrm{n} / \mathrm{a}$ & $\mathrm{n} / \mathrm{a}$ & $\mathrm{n} / \mathrm{a}$ & $\mathrm{n} / \mathrm{a}$ \\
\hline & $2005-2012$ & - & - & - & - & - \\
\hline \multirow[t]{2}{*}{ Czech Rep } & $2000-2007$ & 10.0317 & 15.4947 & 0.2783 & - & - \\
\hline & $2005-2012$ & - & - & - & - & - \\
\hline \multirow[t]{2}{*}{ Greece } & $2000-2007$ & 6.38059 & 15.4947 & 0.6505 & - & - \\
\hline & $2005-2012$ & 7.84840 & 15.4947 & 0.4817 & - & - \\
\hline \multirow[t]{2}{*}{ Hungary } & $2000-2007$ & - & - & - & - & - \\
\hline & $2005-2012$ & 8.32172 & 15.4947 & 0.4316 & - & - \\
\hline \multirow[t]{2}{*}{ Macedonia } & $2000-2007$ & $n / a$ & $\mathrm{n} / \mathrm{a}$ & $\mathrm{n} / \mathrm{a}$ & $\mathrm{n} / \mathrm{a}$ & $\mathrm{n} / \mathrm{a}$ \\
\hline & $2005-2012$ & 17.6672 & 20.2618 & 0.1095 & - & - \\
\hline \multirow[t]{2}{*}{ Moldova } & $2000-2007$ & - & - & - & - & - \\
\hline & $2005-2012$ & 16.6693 & 20.2618 & 0.1454 & - & - \\
\hline \multirow[t]{2}{*}{ Poland } & $2000-2007$ & - & - & - & - & - \\
\hline & $2005-2012$ & 6.85342 & 15.4947 & 0.5948 & - & - \\
\hline \multirow[t]{2}{*}{ Romania } & $2000-2007$ & 11.7139 & 15.4947 & 0.1712 & - & - \\
\hline & $2005-2012$ & - & - & - & - & - \\
\hline \multirow[t]{2}{*}{ Slovakia } & $2000-2007$ & $\mathrm{n} / \mathrm{a}$ & $\mathrm{n} / \mathrm{a}$ & $\mathrm{n} / \mathrm{a}$ & $\mathrm{n} / \mathrm{a}$ & $\mathrm{n} / \mathrm{a}$ \\
\hline & $2005-2012$ & 8.35516 & 15.4947 & 0.4282 & - & - \\
\hline \multirow[t]{2}{*}{ Slovenia } & $2000-2007$ & 8.14369 & 15.4947 & 0.4502 & - & - \\
\hline & $2005-2012$ & - & - & - & - & - \\
\hline \multirow[t]{2}{*}{ Turkey } & $2000-2007$ & 34.3372 & 15.4947 & 0.0000 & $-1.00015^{* * *}$ & $0.34123^{* * *}$ \\
\hline & $2005-2012$ & 21.6133 & 20.2618 & 0.0324 & $-0.53627 * * *$ & $-0.64365 * * *$ \\
\hline \multirow[t]{2}{*}{ Ukraine } & $2000-2007$ & $n / a$ & $\mathrm{n} / \mathrm{a}$ & $\mathrm{n} / \mathrm{a}$ & $\mathrm{n} / \mathrm{a}$ & $\mathrm{n} / \mathrm{a}$ \\
\hline & $2005-2012$ & - & - & - & - & - \\
\hline
\end{tabular}

Notes: Standard errors are in parenthesis. ${ }^{* * *}$ denotes the significance at $1 \%$ level. The hypothesis of Johansen Cointegration Test is $\mathrm{H}_{0}: r=0, \mathrm{H}_{a}=r \geq 1$. $\mathrm{n} / \mathrm{a}$ indicates that the tests can not be estimated because of the data limitation. 
We next move to the second traditional approach to examining the issue of sustainability (cointegration analysis), which we implement using the Johansen cointegration test (Johansen, 1988; Johansen and Juselius, 1990). Application of this requires that our series are first-difference stationary. Similar to our unit root analysis, we examine the order of integration of exports and imports-augmented by using the generalised least squares (GLS) detrended version of the conventional Dickey-Fuller test (DFGLS or ERS test) proposed by Elliott et al. (1996) and a modified version of the Phillips-Perron tests proposed by Ng and Perron (2001). The unit root test results for exports and imports-augmented are presented in Online Resource 1 and Online Resource 2. According to the test results, the exports and importsaugmented series are first difference stationary only for some countries. Hence, we apply this analysis to the subset of countries whose exports and imports-augmented series meet this criterion and present empty cells in Table 2 for the rest.

In contrast to unit root analysis results, the cointegration analysis for current account sustainability - i.e., for the exports and imports-augmented series - using the Johansen cointegration test (Johansen, 1988; Johansen and Juselius, 1990) provides more limited evidence in favour of sustainability. Indeed, as is depicted in Table 2, a cointegrating relationship is obtained only for Turkey in the pre-crisis period and for Bulgaria, Croatia and Turkey post-crisis. ${ }^{9}$ Even in these cases, however, evidence of current account sustainability appears to be of the weak form as, despite the presence of a cointegration relationship, the condition for strong-form sustainability

\footnotetext{
${ }^{9}$ For Belarus, although the long-run coefficient is negative and significant, the error-correction term has the wrong sign and it is not significant statistically.
} 
(namely, that the long run coefficient is equal to 1 - Baharumshah et al., 2003) is not met.

All in all, the evidence on sustainability derived so far is rather mixed. Descriptive patterns, as reviewed in the previous sub-section, suggest significant and rather persistent imbalances in a large number of countries and negative external positions for all, throughout the period. The evidence from the traditional econometric tests in this section is in turn more mixed: we find sizeable evidence of sustainability, but not fully consistent across periods and aggregates (CA versus NFA positions), in the unitroot analysis; and limited evidence of sustainability in the cointegration analysis. Given this, we turn the focus of our analysis to the error correction approach proposed by Bohn (2007). As has been discussed previously, Bohn's (2007) methodology provides for a more comprehensive (less narrow) and less restrictive test for sustainability, which allows us to look jointly at the trade and capital accounts and thus at the overall intertemporal budget constraint.

\subsection{External sustainability in an error correction framework}

The first and second propositions of Bohn (2007) require that in order for the intertemporal budget constraint and the transversality condition to hold, exports, imports and net foreign assets should be integrated of a finite order. Subject to this, the third proposition prescribes the estimation of an error-correction specification (as in equation 1) and requires that for external sustainability to hold both the errorcorrection and long-run coefficients should be statistically significant and negative. To 
examine that the first two propositions hold in our data, we test the order of integration of the relevant series by drawing on the generalised least squares (GLS) detrended version of the conventional Dickey-Fuller test (DFGLS or ERS test) proposed by Elliott et al. (1996) and a modified version of the Phillips-Perron tests proposed by Ng and Perron (2001). Our results (see Online resource 1 and Online Resource 2) show that conditions for external sustainability, as derived in Bohn's (2007) definition, exist in all countries and in both periods, as all the series are integrated of a finite order and typically of order 1 or 2 . We thus move on to the nonlinear estimation of equation 1 . We report results separately for each country and by sub-period, in Table 3.

In the first sub-period the error correction coefficient is negative for all of the countries, but it is only significant statistically for Belarus, Bulgaria, Croatia, the Czech Republic, Hungary, Moldova, Poland and Slovenia. For these countries, our results indicate that an equilibrium relationship between net exports and net foreign assets exists. However, in none of these countries is the long-run coefficient simultaneously negative and statistically significant. ${ }^{10}$ It follows that, on the basis of Bohn (2007)'s definition of sustainability, no country in our data presents a strong or conclusive case of external sustainability. Recall that in our earlier analysis for the pre-crisis period, we found evidence of weak sustainability for Turkey from the cointegration analysis and consistent evidence for sustainability (in the sense that both the CA and the NFA positions appeared stationary) from the unit root analysis for Belarus, Croatia, the Czech Republic, Hungary and Slovenia. Given that, unlike the traditional tests, the

\footnotetext{
${ }^{10}$ The coefficient is statistically significant but positive for the Czech Republic, Hungary, Moldova and Poland.
} 
error-correction approach looks jointly at the co-movement of the net exports (for Bohn's methodology net exports represents a country's current account position without interest and transfer payments) and (lagged) net foreign assets positions, we can conclude that, in combination, these two series did not contribute to maintaining a non-explosive long-run trajectory for the overall intertemporal budget constraint even in countries where both the CA nad NFA seriesappear stationary.

Table 3. Non-Linear Least Squares Estimations

\begin{tabular}{|c|c|c|c|c|}
\hline \multirow[b]{2}{*}{ Countries } & \multicolumn{2}{|c|}{$2000 q 1-2007 q 4$} & \multicolumn{2}{|c|}{$2005 q 1-2012 q 4$} \\
\hline & $\begin{array}{l}\text { Long-run } \\
\text { Coefficient }\end{array}$ & $\begin{array}{l}\text { Error-Correction } \\
\text { Coefficient }\end{array}$ & $\begin{array}{l}\text { Long-run } \\
\text { Coefficient }\end{array}$ & $\begin{array}{l}\text { Error-Correction } \\
\text { Coefficient }\end{array}$ \\
\hline Belarus & $\begin{array}{l}0.0072179 \\
(0.0274615)\end{array}$ & $\begin{array}{l}-1.269695 * * * \\
(0.4458567)\end{array}$ & $\begin{array}{l}0.0665195 \\
(0.0655742)\end{array}$ & $\begin{array}{l}-0.429864 * \\
(0.2260168)\end{array}$ \\
\hline Bulgaria & $\begin{array}{l}-0.0142602 \\
(0.025928)\end{array}$ & $\begin{array}{l}-0.7692935^{* *} \\
(0.319237)\end{array}$ & $\begin{array}{l}-0.012714 \\
(0.0182173)\end{array}$ & $\begin{array}{l}-0.6004619 * * * \\
(0.1818548)\end{array}$ \\
\hline Croatia & $\begin{array}{l}0.0067931 \\
(0.1735945)\end{array}$ & $\begin{array}{l}-1.181318^{* * *} \\
(0.0063268)\end{array}$ & $\begin{array}{l}0.0223536 \\
(0.0699674)\end{array}$ & $\begin{array}{l}-0.1133199 \\
(0.127408)\end{array}$ \\
\hline Cyprus & & & $\begin{array}{l}0.0125218 \\
(0.0078251)\end{array}$ & $\begin{array}{l}-0.6176266 * * * \\
(0.2166033)\end{array}$ \\
\hline Czech Rep. & $\begin{array}{l}0.0664756 * * * \\
(0.1528972)\end{array}$ & $\begin{array}{l}-0.439224 * * * \\
(0.0094585)\end{array}$ & $\begin{array}{l}0.0172922^{*} \\
(0.0090309)\end{array}$ & $\begin{array}{l}-0.7618344^{* *} \\
(0.341094)\end{array}$ \\
\hline Greece & $\begin{array}{l}-0.0244693 \\
(0.0193737)\end{array}$ & $\begin{array}{l}-0.2443439 \\
(0.1445799)\end{array}$ & $\begin{array}{l}0.1123113 \\
(0.3801387)\end{array}$ & $\begin{array}{l}-0.0462076 \\
(0.1350361)\end{array}$ \\
\hline Hungary & $\begin{array}{l}0.022595 * * \\
(0.009601)\end{array}$ & $\begin{array}{l}-0.4947934 * * * \\
(0.1292634)\end{array}$ & $\begin{array}{l}0.1805709 \\
(0.3370387)\end{array}$ & $\begin{array}{l}-0.0369041 \\
(0.0821121)\end{array}$ \\
\hline Macedonia & & & $\begin{array}{l}-0.1213015^{* *} \\
(0.0465147)\end{array}$ & $\begin{array}{l}-0.6018725 * * * \\
(0.1876797)\end{array}$ \\
\hline Moldova & $\begin{array}{l}0.1258841 * * * \\
(0.0997486)\end{array}$ & $\begin{array}{l}-0.2825495^{* * *} \\
(0.0386391)\end{array}$ & $\begin{array}{l}0.1551959 * * * \\
(0.0552522)\end{array}$ & $\begin{array}{l}-0.4805722^{* * *} \\
(0.1621968)\end{array}$ \\
\hline Poland & $\begin{array}{l}0.0166343^{*} \\
(0.0091872)\end{array}$ & $\begin{array}{l}-0.5511516^{* *} \\
(0.2383575)\end{array}$ & $\begin{array}{l}0.0224525 \\
(0.0197249)\end{array}$ & $\begin{array}{l}-0.28102 \\
(0.1752566)\end{array}$ \\
\hline Romania & $\begin{array}{l}-0.082419 * \\
0.0411634\end{array}$ & $\begin{array}{l}-0.2854791 \\
0.2046475\end{array}$ & $\begin{array}{l}0.0647758 * * \\
(0.0247077)\end{array}$ & $\begin{array}{l}-0.1679193 \\
(0.1050988)\end{array}$ \\
\hline Slovakia & & & $\begin{array}{l}-0.0437007 \\
(0.3535442)\end{array}$ & $\begin{array}{l}-0.0642202 \\
(0.1364299)\end{array}$ \\
\hline Slovenia $^{\dagger}$ & $\begin{array}{l}-0.012999 \\
(0.0129567)\end{array}$ & $\begin{array}{l}-1.051418 * * \\
(0.4615551)\end{array}$ & & \\
\hline Turkey & $\begin{array}{l}-0.0027216 \\
(0.0316807)\end{array}$ & $\begin{array}{l}-0.6189606 \\
(0.4616373)\end{array}$ & $\begin{array}{l}-0.0805475^{* * *} \\
(0.023923)\end{array}$ & $\begin{array}{l}-0.4010862 * * * \\
(0.1199406)\end{array}$ \\
\hline Ukraine & & & $\begin{array}{l}0.0536859 \\
(0.0780155)\end{array}$ & $\begin{array}{l}-0.2047898 \\
(0.1482598)\end{array}$ \\
\hline
\end{tabular}

Notes: $* * *, * *, *$ denote significance at $1 \%, 5 \%$ and $10 \%$ respectively. Standard Errors are in parentheses. Missing estimations in the first period are due to missing data. ${ }^{\dagger}$ For Slovenia in $2005 q 1-$ $2012 q 4$ the model did not converge and thus no parameters could be estimated. 
The situation seems to have changed somewhat, albeit by no means drammatically, in the second sub-period (right-hand panel of Table 3). As before, all error-correction coefficients are negative but they are statistically significant for only a subset of countries. Evidence of an equilibrium relationship between net exports and net foreign assets is found this time for two of the four countries not covered in the analysis of the first sub-period (Cyprus and Macedonia), four of the countries which returned negative and statistically significant error correction coefficients also precrisis (Belarus, Bulgaria the Czech Republic and Moldova), as well as for one country for which no equilibrium relationship was found pre-crisis (Turkey). In contrast, for Croatia, Hungary and Poland the evidence of an equilibrium relationship found earlier does not seem to hold for the second sub-period. This time however, two countries Macedonia and Turkey - show evidence of sustainability beyond this minimum condition, in the sense that they also return a significant and negative long-run coefficient.

These results are very informative and broadly consistent with our broader empirical observations. Concerning the cases of Macedonia and Turkey, we noted in section 4.1 that these two countries had comparatively rather manageable current account deficits (sub-period averages of $4.7 \%$ and $5.8 \%$, respectively) and medium levels of NFA positions (sub-period averages of $-226 \%$ and $-162 \%$, respectively); while the traditional tests also returned strong evidence of sustainability (for the CA and NFA series of Macedonia in the unit root tests and for the NFA unit-root test and the cointegration analysis for Turkey). This, however, should not be taken to imply that 
these conditions necessarily ensure sustainability in the error-correction formulation. Indeed, our results for Belarus show that an equilibrium relationship between net exports and net foreign assets can exist without either of the series meeting the strict stationarity condition of the unit root tests. Some general pattern, however, does emerge from our remaining results. In all cases where the error correction coefficient is significant and negative but the long-run coefficient is not (Bulgaria, Cyprus, the Czech Republic and Moldova), the traditional results show countries to meet the criterion of current account sustainability but to have non-stationary NFA positions. This suggests that non-sustainability in these cases derives not from the nonstationarity of the current account itself but from its lack of dynamic adjustment to changes in net foreign assets. Inversely, all countries (except Croatia) for which we do not obtain a significant error correction coefficient, show evidence of stationarity in the NFA series but not in the current account in the traditional analyses. ${ }^{11}$ This in turn shows that 'sustainability' of net foreign assets is a poor indicator of overal external sustainability (in the sense of the intertemporal budget constraint implied in the error correction approach and the equilibrium-correcting relationship between the two external accounts).

\subsection{Robustness checks}

Our investigation so far has separated in an ad hoc fashion between the pre-crisis and post-crisis periods, in this way also imposing a limiting constraint on our estimating

\footnotetext{
${ }^{11}$ Interestingly, these countries also exhibit comparable evolutions during the period in their NFA and CA series (see Figures 1 and 2).
} 
sample size (32 observations per country). To examine how sample size may be affecting our results, we have replicated the analysis presented thus far, using the full time-horizon of our sample (2000q1-2012q4), allowing this time for the possibility of one structural break. For brevity, we do not report on the full set of obtained results, but offer an indicative summary (full results are given in Online Resource 3 for unit root analysis, Online Resource 4 for cointegration analysis and Online Resource 5 for non-linear least squares estimation.).

In order to investigate the stationarity properties of the series we apply the Clemente-Montanes-Reyes test (Clemente et al., 1998; Perron and Vogelsang, 1992) to the level of the series by taking into account one structural break and when we take the first difference of the series we use the generalised least squares (GLS) detrended version of the conventional Dickey-Fuller test (DFGLS or ERS test) proposed by Elliott et al. (1996). For the CA balance, evidence of sustainability in the full period, under the hypothesis of a structural break, is found for the Czech Republic, Belarus, Croatia, Hungary, Cyprus and Slovakia (with the majority of structural breaks occurring between 2007q3 and 2009q2). In the period-specific analysis the first of these countries was found to have sustainable CA balances in both sub-periods; the next three were found to have sustainable CA balances for the precrisis period only; and for the last two CA sustainability was only found in the postcrisis period. Poland, Romania, Slovenia, Moldova and Macedonia, for which some evidence of CA sustainability was found in the period-specific analysis, do not return statistically significant evidence of sustainability in the full-period analysis even under the assumption of a structural break. 
For the NFA position, as was the case with the sub-periods analysis, evidence of sustainability is generally weaker and statistically significant only for a small sub-set of countries: Hungary (for which NFA sustainability was also found seperately for each of the sub-periods; and the only case in the full-period analysis where consistent across-measures evidence of sustainability is found), Moldova and Ukraine. For the last two countries evidence of NFA sustainability is unique to the full-period analysis, and the estimated optimal points for the structural break (2003q3 and 2009q2, respectively) are in both cases outside the timeframe of our ad hoc periodization into sub-periods.

Similar evidence of consistency between the sub-periods and full-period analysis is also found for the case of the cointegration analysis. The full-sample cointegration analysis, implemented via the Gregory-Hansen (1996) test, produces evidence of a significant error-correction relationship only for Belarus and Bulgaria (error correction terms of -0.905 and -0.399 , respectively); but in both cases, the long-run coefficients, although statistically significant, are positive and statistically very different from one, implying weak-form cointegration for these two countries. For the Czech Republic, Hungary and Slovakia the evidence for cointegration is less consistent across tests (ADF and $z$ tests across the four Gregory-Hansen (1996) models) and the error correction coefficients are not statistically significant; while for Greece, Romania, Slovenia and Ukraine the ADF and $z$ tests consistently fail to reject the null of no cointegration, under all four Gregory-Hansen (1996) models. This is consistent with the cointegration analysis for the sub-periods reported in section 4.2: for Belarus and Bulgaria the earlier results seem to extend now to the full period under the 
assumption of a structural break (around 2007 and 2009 in the two countries, respectively); while for Coratia and Turkey, the full-period analysis finds no evidence of first-order stationarity in the relevant series and thus the presence of a cointegration relationship cannot be formally examined.

Finally, the non-linear least squares estimation results for the full period return only one country, Turkey, for which external imbalances are sustainable (having both error correction and long-run coefficients negative and significant). This is fully consistent with the sub-periods analysis, where Turkey was the only country amongst the ones examined here ${ }^{12}$ that showed sustainability in any of the two sub-periods. A number of other countries (Belarus, Bulgaria, Croatia, Cyprus, the Czech Republic, Moldova, Slovakia, Slovenia and Ukraine) return a statistically significant and negative errorcorrection coefficient but, as was the case with the sub-periods analysis, none of these countries returns a statistically significant and negative long-run coefficient. Thus, consistently between the sub-periods and full-period analyses, although a longrun relationship is found to exist for these countries, deviations from equilibrium do not seem to follow a convergent path and are thus unstable.

\section{Conclusion}

\footnotetext{
12 Note that for the other country, Macedonia, our data go only back to 2005 and thus a full-period analysis cannot be implemented.
} 
In this study we investigated the sustainability of external imbalances over the period 2000-2012 in 15 countries of the broader European periphery, which have experienced continued negative balances in their external account and significant challenges of adjustment during the recent crisis. Our analysis provides fresh evidence for a set of countries which are relatively under-studied but are collectively of systemic importance; and it does so in an extensive way, utilising alternative but complimentary approaches to testing for sustainability. Additionally, the analysis incorporates measures and techniques which are designed to address recently identified problems with the traditional approaches to the issue: our core analysis (a) takes into account the impact on external sustainability emanating from changes in capital gains and losses (Gourinchas and Rey, 2007) and (b) employes a specification that allows us to look jointly at the current and capital accounts and thus at the intertemporal budget constraint of the current account (Bohn, 2007). We pay attention on how the sustainability of external imbalances changed in our sample with the crisis, by testing sustainability separately across two sub-periods and, alternatively, by allowing for endogenously estimated structural breaks in the longrun relationships examined.

Despite the presence of significant imbalances as revealed by simple inspection of the raw data, according to the results of the traditional unit root analysis a large number of countries appear to meet the sufficiency condition for sustainability (stationary CA or NFA series). This includes Belarus, Croatia, the Czech Republic, Greece, Hungary, Moldova, Poland, Romania,Slovenia and Turkey in the pre-crisis period and Bulgaria, Cyprus, the Czech Republic, Greece, Hungary, Macedonia, Moldova, Slovakia, Slovenia 
and Turkey in the period around the crisis. However, the results from the cointegration tests find only a narrower set of countries meeting the criterion of sustainability, and still only in its weak form (not meeting the $\rho=1$ criterion) - namely Turkey in the first period and Bulgaria, Croatia and Turkey in the second period.

As we explained, despite the appeal and wide use of these approaches to testing for sustainability of external imbalances, both suffer from a number of limitations. This concerns both methodological issues (namely, the critique on the restrictive condition for first-order difference stationarity) and analytical ones (namely, that sustainability should be examined in relation to the intertemporal budget constraint and thus in relation to the co-movement between the current account and NFA series). When taking these considerations on board, we find current account sustainability to be less prevalent in our sample, with no country showing evidence of sustainability in the pre-crisis period and only Macedonia and Turkey having sustainable current accounts in the more recent period. ${ }^{13}$

This pattern, of scarcer evidence of sustainability in a statistically less restrictive (but otherwise more intuitive and comprehensive) framework, seems to us to reinforce the concerns implied by the above considerations about the validity and information value of the traditional approaches to the issue. It appears that, at least in the context of the EU's eastern and super-periphery, even in cases where current account balances are not explosive (i.e., they are stationary), the sustainability of external imbalances is not warranted. As these countries have typically low domestic savings ratios and limited capital bases, they are open to substantial vulnerabilities in relation

\footnotetext{
13 As discussed, Turkey also shows evidence of sustainability also for the full period, under the assumption of one endogenous structural break.
} 
both to the continuity of capital inflows and to changes in capital gains and losses emanating from international capital movements and exchange rate changes. Methodologically, this seems to support the critique applied by Bohn (2007), both with regard to the estimation of sustainability and with regard to the need for sustainability to be assessed on the grounds of the economic (and political) realities characterising the countries under study and their international environment. In terms of policy, our results suggest that the countries of the European periphery and super-periphery face problems and vulnerabilities that go beyond simple concerns about price competitiveness of exports and trade performance at large and rather concern the ability of these countries to maintain sustainable levels of foreign and domestic investment that will allow the continuing financing of their external deficits in their path to economic development and catch-up with the development levels of the European core.

To conclude, concerns about the sustainability of external imbalances in the European periphery and super-periphery appear to be well founded on the grounds of both the descriptive and the econometric evidence. Although all of the econometric tests applied here examine (various versions of) a sufficient condition for sustainability, and in this sense failure to accept sustainability does not necessarily imply unsustainability, it appears warranted to conclude that most of the countries under study have been, and still are, in a rather vulnerable position with regard to their external balances. Given the relatively low levels of development of these countries and their continuing dependence on international trade (exports) and investment (capital inflows), it appears of paramount importance that policy efforts 
continue to pay attention to the fiscal and financial stability of these countries not only in the current climate but also prospectively in the period after the full recovery from the problems still facing today the international economy. 


\section{References}

Andre, C., Balcilar, M., Chang, T., Gil-Alana, L. A., Gupta, R. (2018). “Current Account Sustainability in G7 and BRICS: Evidence from a Long-memory Model with Structural Breaks", The Journal of International Trade and Economic Development, 27(6), 638-654, DOI: 10.1080/09638199.2017.1410853.

Apergis, N., Katrakilidis, K. P., Tabakis, N. M. (2000). "Current Account Deficit Sustainability: The Case of Greece", Applied Economics Letters, 7(9), 599-603.

Arghyrou, M. G. and Chortareas, G. (2008). "Current Account Imbalances and Real Exchange Rates in the Euro Area", Review of International Economics, 16(4), 747764.

Aristovnik, A. (2008). "Short-term determinants of current account deficits: evidence from Eastern Europe and the former Soviet Union", Eastern European Economics, 46(1), 24-42.

Atoyan, R., Manning, J., Rahman, J. (2013). "Rebalancing: Evidence from Current Account Adjustment in Europe", IMF Working Paper, No: 74, https://www.imf.org/external/pubs/ft/wp/2013/wp1374.pdf.

Baharumshah, A. Z., Lau, E., Fountas, S. (2003). "On the Sustainability of Current Account Deficits: Evience from four ASEAN Countries", Journal of Asian Economics, 14(3), 465-487.

Bajo-Rubio, O., Diaz-Roldan, C., Esteve, V. (2014). "Sustainability of External Imbalances in the OECD Countries", Applied Economics, 46(4), 441-449.Bartlett, W. and Prica, I. (2013). "The deepening Crisis in the European Super-Periphery", Journal of Balkan and Near Eastern Studies, 15(4), 367-382.

Bayer, C. and Hanck, C. (2013). "Combining Non-cointegration Tests", Journal of Times Series Analysis, 34(1), 83-95.

Belke, A. and Dreger, C. (2013). "Current Account Imbalances in the Euro Area: Does Catching up Explain the Development?", Review of International Economics, 21(1), 6-17.

Bhargava, A. (1986). "On the Theory of Testing for Unit Roots in Observed Times Series", Review of Economic Studies, 53(3), 369-384.

Blanchard, O. and Giavazzi, F. (2002). "Current Account Deficits in the Euro Area: The End of the Feldstein-Horioka Puzzle?", Brookings Paper on Economic Activity, 2002(2), 147-186.

Bohn, H. (2007). "Are Stationarity and Cointegration Restrictions Really Necessary for the Intertemporal Budget Constraint?", Journal of Monetary Economics, 54(7), 1837-1847.

Bollano, J. and Ibrahimaj, D. (2015). "Current Account Determinants in Central Eastern European Countries", Graduate Institute of International and Development Studies International Economics Department Working Paper Series, No: HEIDWP0022-2015, http://repec.graduateinstitute.ch/pdfs/Working_papers/ IHEIDWP22-2015.pdf. 
Ca' Zorzi M., Chudik A., Dieppe A. (2009). "Current Account Benchmarks for Central and Eastern Europe: A Desperate Search?", ECB Working Paper Series, No: 995, https://www.ecb.europa.eu/pub/pdf/scpwps/ecbwp995.pdf?a20ceb5bc6e2a6ef 393a547855c4484a.

Camarero, M., Carrion-i-Silvestre, J. L., Tamarit, C. (2013). “Global Imbalances and the Intertemporal External Budget Constraint: A Multicointegration Approach", Journal of Banking and Finance, 37(12), 5357-5372.

Chen, S. W., Xie, Z. (2015). "Testing for Current Account Sustainability under Assumptions of Smooth Break and Nonlinearity", International Review of Economics and Finance, 38, 142-156.

Christopoulos, D., Leon-Ledesma, M. A. (2010). "Current Account Sustainability in the US: What did We Really Know About It?", Journal of International Money and Finance, 29(3), 442-459.

Clemente, J., Montanes, A., Reyes, M. (1998). "Testing for a Unit Root in Variables with a Double Change in the Mean", Economics Letters, 59(2), 175-182.

Cuestas, J. (2013). "The Current Account Sustainability of European Transtion Economies", Journal of Common Market Studies, 51(2), 232-245.

Denton, F. T. (1971). “Adjustment of Monthly or Quarterly Series to Annual Totals: An Approach Based on Quadratic Minimization", Journal of the American Statistical Association, 66(333), 99-102.

Durdu, C. B., Mendoza, E. G., Terrones, M. E. (2013). “On the Solvency of Nations: Cross-country Evidence on the Dynamics of External Adjustment", Journal of International Money and Finance, 32, 762-780.

Elliott, G., Rothernberg, T. J., Stock, J. H. (1996). “Efficient Tests for an Autoregressive Unit Root", Econometrica, 64(4), 813-836.

Engle, R. F. and Granger, C. W. J. (1987). "Co-integration and Error Correction: Representation, Estimation, and Testing", Econometrica, 55(2), 251-276.

Ghironi, F., Lee, J., Rebucci, A. (2015). "The Valuation Channel of External Adjustment", Journal of International Money and Finance, 57, 86-114.

Gourinchas, P. O. and Rey, H. (2007). "International Financial Adjustment", Journal of Political Economy, 115(4), 665-703.

Gregory, A. W. and Hansen, B. E. (1996). "Residual-based Tests for Cointegration in Models with Regime Shifts", Journal of Econometrics, 70(1), 99-126.

Harkmann, K. and Staehr, K. (2012). "Current account balances in Central and Eastern Europe: Heterogeneity, Persistence and Driving Factors", Institute of Economic Studies, Charles University, Prague, http://ies.fsv.cuni.cz/default/file/get/id/20935.

Hasdemir, E., Omay, T., Denaux, Z. S. (2019). "Testing the Current Account Sustainability for BRICS Countries: Evidence from a Nonlinear Framework", Economics Bulletin, 39(1), 310-320.

Herrmann, S. and A. Winkler (2009). "Real Convergence, Financial Markets and the Current Account: Emerging Europe versus Emerging Asia", Economic Papers 362, 
Directorate-General for Economic and Financial Affairs, European Commission, http://ec.europa.eu/economy finance/publications/pages/publication14285 en.pdf.

Holmes, M. J. (2006). "How Sustainable are OECD Current Account Balances in the Long Run?", The Manchester School, 74(5), 626-643.

Hubrich, K., Lütkepohl, H., Saikkonen, P. (2001). "A Review of Systems Cointegration Tests", Econometric Reviews, 20(3), 247-318.

Husted, S. (1992) "The Emerging US Current Account Deficit in the 1980s: A Cointegration Analysis", The Review of Economics and Statistics, 74(1), 159-166.

IMF (International Monetary Fund) (2014). International Finanacial Statistics (IFS), https://data.imf.org/?sk=4C514D48-B6BA-49ED-8AB9-52B0C1A0179B.

Johansen, S. (1988). "Statistical Analysis of Cointegration Vectors", Journal of Economic Dynamics and Control, 12(2-3), 231-254.

Johansen, S. and Juselius, K. (1990). "Maximum Likelihood Estimation and Inference on Cointegration-with Applications to the Demand for Money", 52(2), 169-210.

Kang, J. S. and Shambaugh, J. C. (2013). "The Evolution of Current Account Deficits in the Euro Area Periphery and the Baltics: Many Paths to the Same Endpoint", IMF Working Paper, No: 169, https://www.imf.org/external/pubs/ft/wp/2013/ wp13169.pdf.

Kuo, C. Y. (2016). "Sustainability of Current Accounts: Evidence form the Quantile Unit-root Test", Applied Economics Letters, 23(10), 747-755, DOI: 10.1080/13504851.2015.1105914.

Lane, P. R. and Milesi-Ferretti, G. M. (2007). "The External Wealth of Nations Mark II: Revised and Extended Estimates of Foreign Assets and Liabilities", 1970-2004", Journal of International Economics, 73(2), 223-250.

Lane, P. and Pels, B. (2012). "Current Account Imbalances in Europe", CEPR Discussion Paper, No: DP8958.

Lau, E., Baharumshah, Z., Haw, C. T. (2006). "Current Account: Mean Reverting or Randon Walk Behavior?", Japan and the World Economy, 18(1), 90-107.

Liu, P. C. and Tanner, E. (1996). "International Intertemporal Solvencyin Industrialized Countries: Evidence and Implications", Southern Economic Journal, 62(3), 739749.

Llorca, M. (2017). “External Debt Sustainability and Vulnerabilities: Evidence from a Panel of 24 Asian Countries and Prospective Analysis", ADBI (Asian Development Bank Institute) Working Paper, No: 692, Asian Development Bank Institute (ADBI), Tokyo, https://www.adb.org/sites/default/files/publication/233781/adbiwp692.pdf.

Muharremi, T. I. (2016). "Factors Affecting Current Account in the Balance of Payments of Selected Western Balkan Countries" The Journal of Accounting and Management, 5(3), 61-68.

Ng, S. and Perron, P. (2001). "Lag Length Selection Selection and Constructuion of Unit Root Testswith Good Size and Power", Econometrica, 69(6), 1529-1554. 
Obstfeld, M. (2012). "Does the Current Account Still Matter?", NBER Working Paper No: 17877, http://www.nber.org/papers/w17877.pdf.

Oyon-Amba, M. C., Mbratana, T., Kane, Q. G. (2017). “Assessing the Current Account Sustainability in ECCAS Economies: A Dual Cointegration Analysis", MPRA Paper, No: 79942, https://mpra.ub.uni-muenchen.de/79942/.

Pedroni, P. (1999). "Critical Values for Cointegration Tests in Heterogeneous Pnels with Multiple Regressors", Oxford Bulletin of Economics and Statistics, 61(S1), 653-670.

Pedroni, P. (2004). "Panel Cointegraiton: Asymptotic and Finite Sample Properties of Pooled Time Series Tests with an Application to the PPP Hypothesis", Econometric Theory, 20(3), 597-625.

Perron, P. and Vogelsang, T. J. (1992). "Nonstationarity and Level Shifts with an Application to Purchasing Power Pairty", Journal of Business and Economic Statistics, 10(3), 301-320.

Phillips, P. C. B. and Perron, P. (1988). "Testing for a Unit Root in Time Series Regression", Biometrika, 75(2), 335-346.

Purfield, C. and Rosenberg, C. B. (2010). “Adjustment under a Currency Peg: Estonia, Latvia and Lithuania during the Global Financial Crisis 2008-09", IMF Working Paper, No:

$10 / 213$

https://www.imf.org/en/Publications/WP/Issues/2016/12/31/Adjustment-Under-a-

Currency-Peg-Estonia-Latvia-and-Lithuania-During-the-Global-Financial-24217.

Roubini, N. and Wachtel, P. (1998). "Current Account Instability in Transition Economies", NBER Working Paper, No: 6468, http://www.nber.org/papers/w6468.pdf.

Sadiku, L., Fetahi-Vehapi, M., Sadiku, M., Berisha, N. (2015). "The Persistence and Determinants of Current Account Deficit of FYROM: An Empirical Analysis" Procedia Economics and Finance, 33, 90-102.

Sahoo, M., Babu, M. S., Dash, U. (2016). “Long Run Sustainability of Current Account Balance of China and India: New Evidence from Combined Cointegration Test", Intellectual Economics, 10(2), 78-91.

Schoder, C., Proano, C. R., Semmler, W. (2013). "Are Current Account Imbalances between EMU Countries Sustainable? Evidence from Parametric and NonParametricTests", Journal of Applied Econometrics, 28(7), 1179-1204.

Semmler, W. and Tahri, I. (2017). "Current Account Imbalances: A New Approach to Assess External Debt Sustainability", Economic Modelling, 62, 161-170.

Shastri, S., Giri, A. K., Mohapatra, G. (2018). "Testing the Sustainability of Current Accounts for Major South Asian Economies: A Panel Data Approach", South Asia Economic Journal, 19(1), 1-21.

Sinn, H. W. (2015). “Europe's Keynesian Dream-A Neo-Classical Recipe for a NeoClassical Problem", The International Economy, Winet 2015, 38-39-56. 
Trehan, B. and Walsh, C. E. (1991). "Testing Intertemporal Budget Constraints: Theory and Applications to the US Fedaral Budget and Current Account Deficits", Journal of Money, Credit and Banking, 23(2), 206-223.

Westerlund, J. (2007). "Testing for Error Correction in Panel Data", Oxford Bulletin of Economics and Statistics, 69(6), 709-748.

Wickens, M. R. and Uctum, M. (1993). "The Sustainability of Current Account DeficitsA Test of the US Intertemporal Budget Constraint", Journal of Economic Dynamics and Control, 17(3), 423-441.

Wu, J. L. (2000). "Mean Reversion of the Current Account: Evidence from the Panel Data Unit Root Test", Economics Letters, 66(2), 215-222.

Wu, J. L., Chen, S. L., Lee, H. Y. (2001). “Are Current Account Deficits Sustainable? Evidence from Panel Cointegration", Economics Letters, 72(2), 219-224.

Wu, J. L., Fountas, S., Chen, S. L. (1996). "Testing for the sustainability of the Current Account Deficit in Two Industrial Countries", Economics Letters, 52(2), 193-198.

Zemanek, H., Belke, A., Schnabl, G. (2010). "Current Account Balances and Structural Adjustment in the Euro Area", International Economics and Economics Policy, 7(1), 83-127. 